\title{
Mechanism and regulation of translation in C. elegans ${ }^{\star}$
}

\author{
Robert E. Rhoads ${ }^{\mathcal{S}}$, Tzvetanka D. Dinkova ${ }^{\dagger}$, Nadejda L. Korneeva, \\ Department of Biochemistry and Molecular Biology, Louisiana State \\ University Health Sciences Center, Shreveport, Louisiana, 71130-3932 \\ USA
}

\section{Table of Contents}

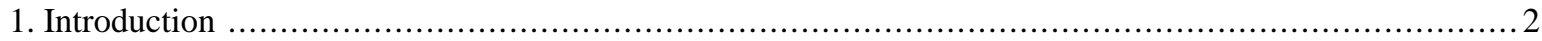

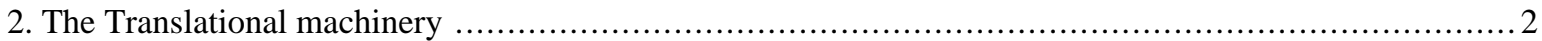

2.1. Mechanism of translation in eukaryotes ......................................................... 2

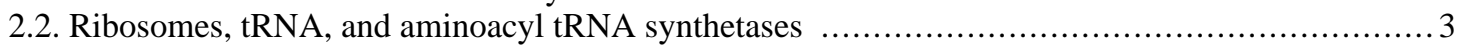

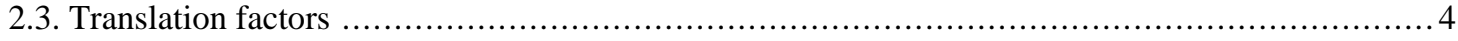

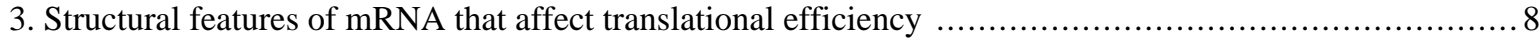

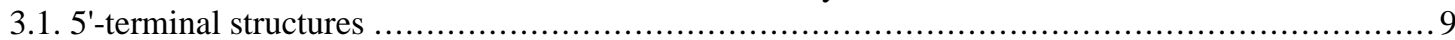

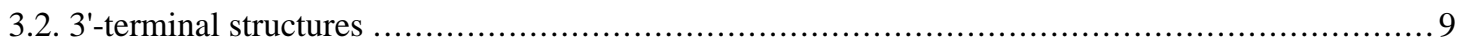

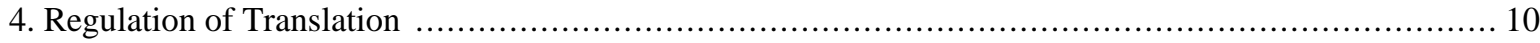

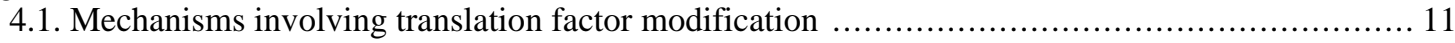

4.2. Mechanisms involving mRNA modification ................................................. 11

4.3. Known instances of translational regulation that occur but through unknown mechanisms ........ 12

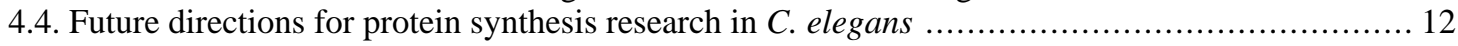

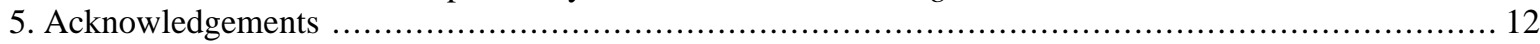

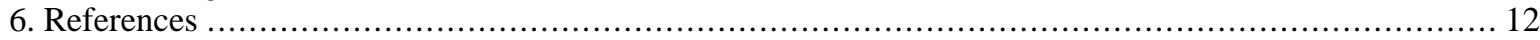

\begin{abstract}
C. elegans represents a favorable system to study the extraordinarily complicated process of eukaryotic protein synthesis, which involves over 100 RNAs and over 200 polypeptides just for the core machinery. Initial research in protein synthesis relied on fractionated mammalian and plant systems, but in the mid-1970s, the powerful genetics of Saccharomyces cerevisiae began to yield new insights for translation in all
\end{abstract}

*Edited by Thomas Blumenthal. Last revised January 12, 2005. Published January 28, 2006. This chapter should be cited as: Rhoads, R. E. et al. Mechanism and regulation of translation in C. elegans (January 28, 2006), WormBook, ed. The C. elegans Research Community, WormBook, doi/10.1895/wormbook.1.63.1, http://www.wormbook.org.

Copyright: () 2006 Robert E. Rhoads et al. This is an open-access article distributed under the terms of the Creative Commons Attribution License, which permits unrestricted use, distribution, and reproduction in any medium, provided the original author and source are credited.

${ }^{\S}$ To whom correspondence should be addressed. E-mail: rrhoad@1suhsc.edu

${ }^{\dagger}$ Current address: Departamento de Bioquimica, Facultad de Quimica, Universidad Nacional Autonoma de Mexico, 04510, Mexico DF, Mexico 
eukaryotes. $C$. elegans has many features of higher eukaryotes that are not shared by yeast. This allows protein synthesis researchers to combine biochemistry, cell biology, developmental biology, genetics, and genomics to study regulation of gene expression at the translational level. Most components of the core translational machinery have been identified in $C$. elegans, including rRNAs, 5S RNA, tRNAs, ribosomal proteins, and aminoacyl tRNA synthetases. $C$. elegans has amino acid sequence homologs for 56 of the known initiation, elongation, and release factor polypeptides, but few of these have been isolated, functionally identified, or studied at the biochemical level. Similarly, $C$. elegans has homologs for 22 components of the major signal transduction pathways implicated in control of protein synthesis. The translational efficiency of individual mRNAs relies on cis-regulatory elements that include either a 7-methylguanosine- or 2,2,7-trimethylguanosine-containing cap, the 5'-terminal spliced leader, sequence elements in the 3 '-untranslated regions, and the 3'-terminal poly(A) tract. Several key developmental pathways in $C$. elegans are predominantly governed by translational mechanisms. Some evidence has been presented that well described regulatory mechanisms in other organisms, including covalent modification of translation factors, sequestration of translation factors, and mRNA-specific changes in poly(A) length, also occur in $C$. elegans. The most interesting unexplored questions may involve changes in the translation of individual mRNAs during development, in response to physiological changes, or after genetic manipulations. Given the highly developed state of $C$. elegans genomics, it can be expected that future application of computational tools, including data visualization, will help detect new instances of translational control.

\section{Introduction}

Although "gene expression" is often used synonymously with "transcription", the steady-state levels of proteins in eukaryotic cells are also strongly dependent on translational regulatory mechanisms. Two very different types of translational control occur: global and mRNA-specific. Global control generally involves alterations in the levels, intrinsic activities, or availability of translation factors, whereas mRNA-specific control involves proteins or RNAs that interact with a subset of mRNAs. The overall rate of protein synthesis as well as the translational efficiencies of individual mRNAs are regulated in response to nutritional, hormonal, cellular stress, and developmental signals (Sonenberg et al., 2000).

C. elegans represents an especially favorable system to study the extraordinarily complicated process of eukaryotic protein synthesis, which involves over 100 RNAs and over 200 polypeptides just for the core machinery. The first decades of research in eukaryotic protein synthesis relied on fractionated mammalian and plant systems, with little or no input of genetics. This began to change in the 1970's when the powerful genetics of Saccharomyces cerevisiae was brought to bear on central questions in protein synthesis. From this research came important new insights for translation in all eukaryotes, including discovery of the initiation codon scanning mechanism (Sherman and Stewart, 1975), new protein synthesis factors and regulatory kinases (Hinnebusch, 1997), previously unknown interactions among initiation factors (Asano et al., 2000), the core structure of eIF3, the most complex of the initiation factors (Phan et al., 1998), and new regulatory pathways for the control of protein synthesis (Hinnebusch and Fink, 1983). C. elegans, however, has many features of higher eukaryotes that are not shared by yeast, e.g., tissues, organs, muscles, a nervous system, developmental stages, cell lineages, etc., which involve processes regulated at the translational level. Furthermore, signaling pathways leading to protein synthesis are considerably more similar between $C$. elegans and humans than between yeast and humans. Thus, $C$. elegans allows protein synthesis researchers to combine biochemistry, cell biology, genetics, and genomics to understand fundamental questions about the regulation of gene expression at the translational level.

\section{The Translational machinery}

\subsection{Mechanism of translation in eukaryotes}

From studies in mammals, yeasts, and plants, it is known that the three steps of protein synthesis are catalyzed by three groups of proteins: initiation, elongation, and release factors (Hershey and Merrick, 2000). A different class of initiation factors (eIF1, eIF2, etc.) catalyzes each step of initiation (Figure 1). [A uniform nomenclature system for translation factors is used here (Clark et al., 1996)]. A ternary complex of eIF2•GTP•Met-tRNA binds to the 40S ribosomal subunit to form the $43 \mathrm{~S}$ initiation complex. Recruitment of mRNA to the $43 \mathrm{~S}$ initiation complex to form the $48 \mathrm{~S}$ initiation complex requires eIF3, the poly(A)-binding protein (PABP), and the eIF4 proteins. eIF3 is a $\sim 800-\mathrm{kDa}$ multimer that is also required for Met-tRNA binding to the 40S subunit (molecular masses refer to the mammalian factors). PABP is a $70-\mathrm{kDa}$ protein that specifically binds poly(A) and homo-oligomerizes. The eIF4 factors consist of: eIF4A, a 46-kDa RNA helicase; eIF4B, a 70-kDa RNA-binding and RNA-annealing protein; 
eIF4H, a 25-kDa protein that acts with eIF4B to stimulate eIF4A helicase activity; eIF4E, a 25-kDa cap-binding protein; and eIF4G, a $185-\mathrm{kDa}$ protein that specifically binds to and co-localizes all of the other proteins involved in mRNA recruitment on the $40 \mathrm{~S}$ subunit.

$40 S$

Subunit
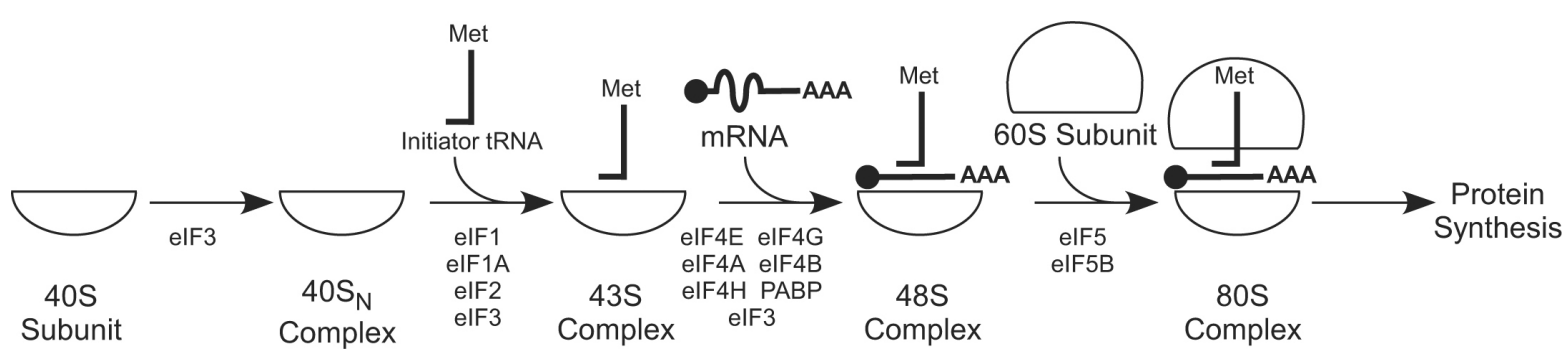

Figure 1. Complexes formed and factors participating in the initiation of protein synthesis.

The 48S complex consists of the eIF4 factors plus PABP, eIF1, eIF1A, eIF3, eIF5, and the eIF2•GTP•Met-tRNA ternary complex bound to the 40S subunit (Figure 2). It scans until the first AUG in good sequence context is encountered. Scanning requires ATP hydrolysis by eIF4A and the presence of eIF1 and eIF1A. Then eIF5 and eIF5B stimulate GTP hydrolysis by eIF2, followed by $60 \mathrm{~S}$ joining to form the $80 \mathrm{~S}$ complex. The released eIF2•GDP is recycled to eIF2 $\bullet$ GTP by the guanine nucleotide exchange factor eIF2B. The first elongator aminoacyl-tRNA is brought to the ribosomal A-site by eEF1, after which the first peptide bond is formed. This is followed by a cycle of GTP hydrolysis and exchange. Translocation is catalyzed by eEF2 with another cycle of GTP hydrolysis and exchange. When the ribosome reaches a termination codon, the release factor eRF1 catalyzes termination, and then the GTPase eRF3 ejects eRF1 from the ribosome.

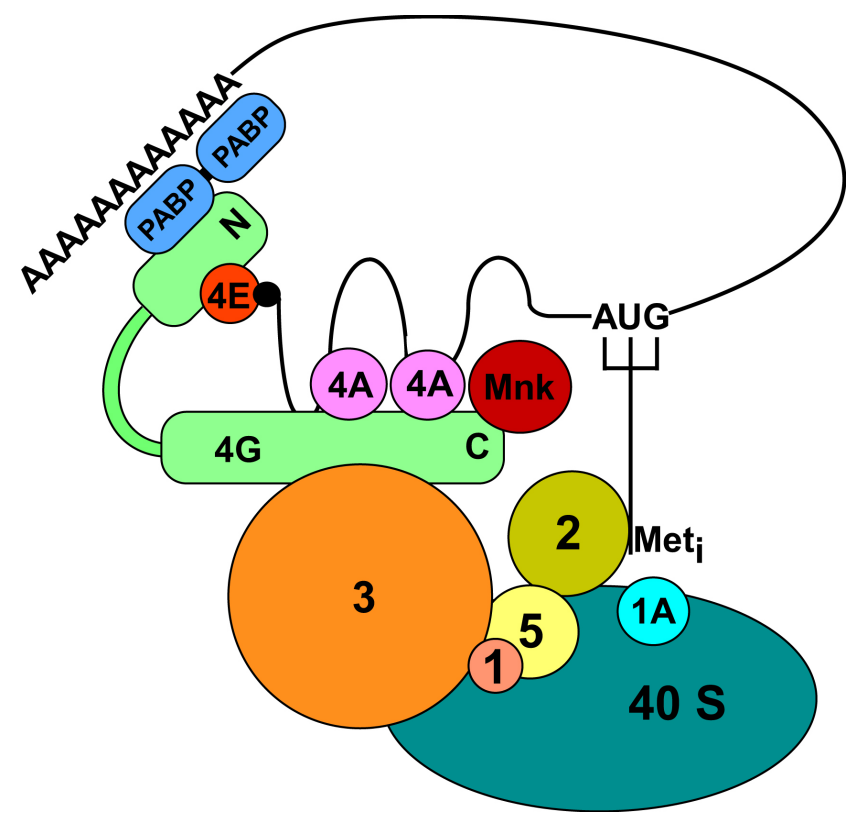

Figure 2. Model for the $\mathbf{4 8 S}$ initiation complex. The interactions among eIF1, eIF2, eIF3, eIF4A, eIF4E, eIF4G, eIF5, Mnk, PABP, mRNA, and the 40S ribosomal subunit are shown. The thin line represents mRNA, with the wavy line indicating mRNA secondary structure. Met is the initiator tRNA. The sizes of protein depictions are roughly proportion to their molecular masses.

\subsection{Ribosomes, tRNA, and aminoacyl tRNA synthetases}

Many components of the translational machinery have been identified in C. elegans, including rRNAs (Albertson, 1984; Ellis et al., 1986; Files and Hirsh, 1981), ribosomal proteins (Jones and Candido, 1993; Zorio et al., 1994; Gonczy et al., 2000), 5S RNA (Nelson and Honda, 1985), tRNA (Schaller et al., 1991; Tranquilla et al., 1982; Khosla and Honda, 1989; Lee et al., 1990), and aminoacyl tRNA synthetases (Amaar and Baillie, 1993; Gabius et al., 1983; Gonczy et al., 2000). 


\subsection{Translation factors}

Of the 56 initiation factor (eIF), elongation factor (eEF), and release factor (eRF) polypeptides that we and others have identified (Table 1), only $\sim 10 \%$ have been isolated and characterized. In the following overview, information not explicitly cited is taken from WormBase, release WS138.

Table 1. C. elegans translational initiation, elongation, and termination factors

\begin{tabular}{|c|c|c|c|c|c|}
\hline $\begin{array}{l}\text { Predicted } \\
\text { translation } \\
\text { factor }\end{array}$ & $\begin{array}{l}\text { Transcript } \\
\text { (splice } \\
\text { variants) }\end{array}$ & $\begin{array}{l}\text { CGC/ Other } \\
\text { names }\end{array}$ & $\begin{array}{l}\text { Predicted identity or } \\
\text { function }\end{array}$ & $\begin{array}{l}\text { Number of } \\
\text { amino acids }\end{array}$ & \begin{tabular}{|} 
Identity to $C$. \\
briggsae/H. \\
sapiens homologs \\
$(\%)$
\end{tabular} \\
\hline \multicolumn{6}{|c|}{ Initiation factors } \\
\hline eIF1 & T27F7.3b & -/PIG-B & Similar to SUI1 & 109 & $100 / 65$ \\
\hline eIF1A & $\mathrm{H} 06 \mathrm{H} 21.3$ & - & $\begin{array}{l}\text { Translation initiation } \\
\text { factor } 1 \mathrm{~A}\end{array}$ & 216 & $72 / 65$ \\
\hline eIF2A & E04D5.1 (a, b) & - & $\begin{array}{l}\text { Contains similarity to } \\
\text { translation initiation } \\
\text { factor eIF2A }\end{array}$ & 618,225 & $96 / 34$ \\
\hline eIF2 $\alpha$ & Y37E3.10 & - & $\begin{array}{l}\text { Translation initiation } \\
\text { factor } 2, \alpha \text { subunit }\end{array}$ & 342 & $88 / 47$ \\
\hline eIF2 $\alpha$ & K04G2.1 & - & $\begin{array}{l}\text { Translation initiation } \\
\text { factor } 2, \alpha \text { subunit }\end{array}$ & 250 & $82 / 58$ \\
\hline eIF2 $\gamma$ & Y39G10AR.8 & - & $\begin{array}{l}\text { Translation initiation } \\
\text { factor } 2, \gamma \text { subunit }\end{array}$ & 469 & $97 / 72$ \\
\hline eIF2B & C01G10.9 & - & $\begin{array}{l}\text { Translation initiation } \\
\text { factor related to } \\
\text { eIF- } 2 B, \alpha / \beta / \delta \text { subunits }\end{array}$ & 366 & $84 / 43$ \\
\hline $\operatorname{eIF} 2 B \alpha$ & ZK1098.4 & - & $\begin{array}{c}\text { eIF-2B, } \alpha \\
\text { subunit/GCN3 }\end{array}$ & 305 & $94 / 42$ \\
\hline eIF2B $\beta$ & Y47H9C.7 & - & eIF-2B, $\beta$ subunit & 340 & $99.7 / 25$ \\
\hline eIF2B $\varepsilon$ & D2085.3 & - & eIF-2B $\varepsilon$ subunit/ GCD6 & 666 & $99.8 / 23$ \\
\hline eIF2B $\gamma$ & C15F1.4 & PPP-1 & $\begin{array}{c}\text { Translation initiation } \\
\text { factor } 2 \mathrm{~B}, \gamma \text { subunit/ } \\
\text { pyrophosphorylase } \\
\text { family }\end{array}$ & 404 & $79 / 29$ \\
\hline eIF2C-1 & T22B3.2 $(\mathrm{a}, \mathrm{b})$ & - & $\begin{array}{l}\text { Translation initiation } \\
\text { factor } 2 \mathrm{C} \text { and related } \\
\text { proteins }\end{array}$ & 1032,1035 & $99.9 / 36$ \\
\hline eIF2C-2 & $\begin{array}{c}\mathrm{ZK} 757.3(\mathrm{a}, \mathrm{b} \\
\mathrm{c})\end{array}$ & TAG-76 & $\begin{array}{l}\text { Translation initiation } \\
\text { factor } 2 \mathrm{C} \text { and related } \\
\text { proteins }\end{array}$ & $1040,1037,55$ & $99.9 / 42$ \\
\hline eIF2C-3 & R09A1.1 & - & $\begin{array}{c}\text { Translation initiation } \\
\text { factor } 2 \mathrm{C}\end{array}$ & 1121 & $98 / 27$ \\
\hline eIF3a & C27D11.1 & EGL-45/eif-3.A & Homologs to eIF3a & 1076 & $72 / 37$ \\
\hline eIF3a & F55H2.6 & CLU-1 & $\begin{array}{l}\text { Involved in } \\
\text { mitochondrial } \\
\text { morphology/ } \\
\text { distribution }\end{array}$ & 1247 & $80 / 40$ \\
\hline eIF3b & Y54E2A.11a & EIF-3.B & $\begin{array}{l}\text { Translation initiation } \\
\text { factor } 3 \text {, subunit b }\end{array}$ & 725 & $89 / 34$ \\
\hline
\end{tabular}




\begin{tabular}{|c|c|c|c|c|c|}
\hline $\begin{array}{l}\text { Predicted } \\
\text { translation } \\
\text { factor }\end{array}$ & $\begin{array}{l}\text { Transcript } \\
\text { (splice } \\
\text { variants) }\end{array}$ & $\begin{array}{l}\text { CGC/ Other } \\
\text { names }\end{array}$ & $\begin{array}{l}\text { Predicted identity or } \\
\text { function }\end{array}$ & $\begin{array}{l}\text { Number of } \\
\text { amino acids }\end{array}$ & \begin{tabular}{|c} 
Identity to $C$. \\
briggsae/H. \\
sapiens homologs \\
$(\%)$
\end{tabular} \\
\hline eIF3c & T23D8.4 & EIF-3.C & $\begin{array}{l}\text { Translation initiation } \\
\text { factor } 3 \text {, subunit c }\end{array}$ & 898 & $89 / 39$ \\
\hline eIF3d & R08D7.3 & EIF-3.D & $\begin{array}{l}\text { Translation initiation } \\
\text { factor } 3 \text {, subunit } d\end{array}$ & 570 & $94 / 45$ \\
\hline eIF3e & B0511.10 & EIF-3.E & $\begin{array}{l}\text { Translation initiation } \\
\text { factor } 3 \text {, subunit e }\end{array}$ & 432 & $74 / 49$ \\
\hline eIF3f & D2013.7 & EIF-3.F & $\begin{array}{l}\text { Translation initiation } \\
\text { factor } 3 \text {, subunit } \mathrm{f}\end{array}$ & 294 & $61 / 35$ \\
\hline eIF3g & F22B5.2 & EIF-3.G & $\begin{array}{l}\text { Translation initiation } \\
\text { factor } 3 \text {, subunit } g\end{array}$ & 256 & $90 / 31$ \\
\hline eIF3h & C41D11.2 & EIF-3.H & $\begin{array}{l}\text { Translation initiation } \\
\text { factor } 3 \text {, subunit } h\end{array}$ & 365 & $97 / 39$ \\
\hline eIF3i & Y74C10AR.1 & EIF-3.I & $\begin{array}{l}\text { Translation initiation } \\
\text { factor } 3 \text {, subunit i }\end{array}$ & 327 & $93 / 43$ \\
\hline eIF3j & Y40B1B.5 & - & \begin{tabular}{|c|} 
Translation initiation \\
factor eIF3, p35 subunit
\end{tabular} & 212 & $69 / 20$ \\
\hline eIF3k & T16G1.11 & EIF-3.K/pqn-69 & $\begin{array}{l}\text { Eukaryotic initiation } \\
\text { factor } 3, \mathrm{p} 25 \text { subunit }\end{array}$ & 240 & $89 / 35$ \\
\hline eIF3I & $\begin{array}{l}\text { C17G10.9 (a.1, } \\
\text { a.2, b) }\end{array}$ & - & $\begin{array}{l}\text { RNA polymerase } \\
\text { I-associated factor - } \\
\text { PAF67 }\end{array}$ & $535-537$ & $99 / 41$ \\
\hline eIF4A & F57B9.6 & INF-1 & $\begin{array}{c}\text { Protein with high } \\
\text { similarity to eukaryotic } \\
\text { initiation factor 4A }\end{array}$ & 402 & $\begin{array}{c}97 / 72 \text { to eIF4A-2, } \\
71 \text { to eIF4A-1 }\end{array}$ \\
\hline eIF4A & F57B9.3 & - & $\begin{array}{l}\text { Translation initiation } \\
\text { factor } 4 \mathrm{~F} \text {, helicase } \\
\text { subunit (eIF4A) and } \\
\text { related helicases }\end{array}$ & 363 & $\begin{array}{l}62 / 52 \text { to eIF4A-1, } \\
51 \text { to eIF4A-2 }\end{array}$ \\
\hline eIF4A-3 & Y65B4A.6 & - & $\begin{array}{l}\text { ATP-dependent RNA } \\
\text { helicase FAL1, } \\
\text { involved in rRNA } \\
\text { maturation }\end{array}$ & 399 & $\begin{array}{c}93 / 82 \text { to eIF4A-3, } \\
66 \text { to eIF4A-2, } 61 \\
\text { to eIF4A-1 }\end{array}$ \\
\hline eIF4A-3 & F33D11.10 & - & $\begin{array}{l}\text { ATP-dependent RNA } \\
\text { helicase FAL1, } \\
\text { involved in rRNA } \\
\text { maturation }\end{array}$ & 399 & $\begin{array}{c}94 / 81 \text { to eIF4A-3, } \\
66 \text { to eIF4A-2, } 62 \\
\text { to eIF4A-1 }\end{array}$ \\
\hline eIF4A-p56 & C07H6.5 & CGH-1 & $\begin{array}{c}\text { Conserved germline } \\
\text { helicase }\end{array}$ & 430 & $\begin{array}{l}\text { 97/71 to DDX6 } \\
\text { (p56); } 40 \text { to } \\
\text { eIF4A-1 }\end{array}$ \\
\hline eIF4A-47 & C26D10.2 $(a, b)$ & HEL-1 & $\begin{array}{l}\text { ATP-dependent RNA } \\
\text { helicase }\end{array}$ & $425 / 268$ & $\begin{array}{l}\text { 97/78 to nuclear } \\
\text { BAT1 (p47) }\end{array}$ \\
\hline eIF4A-DDX47 & T26G10.1 & - & $\begin{array}{c}\text { ATP-dependent RNA } \\
\text { helicase }\end{array}$ & 489 & $-/ 61$ to DDX47 \\
\hline eIF4A-DDX19 & \begin{tabular}{|} 
T07D4.4 $(\mathrm{a}, \mathrm{b}$ \\
$\mathrm{c})$
\end{tabular} & - & $\begin{array}{l}\text { ATP-dependent RNA } \\
\text { helicase }\end{array}$ & $1022,638,613$ & $\begin{array}{l}\text { 99.8/49 to } \\
\text { DDX19 }\end{array}$ \\
\hline eIF4A-Prp5 & F53H1.1 (a, b) & - & RNA helicase & 970,747 & 99.9/46 to Prp5 \\
\hline eIF4B & Y73B6BL.33 & f3 & Splicing factor & 610 & $62 / 31$ \\
\hline
\end{tabular}




\begin{tabular}{|c|c|c|c|c|c|}
\hline $\begin{array}{l}\text { Predicted } \\
\text { translation } \\
\text { factor }\end{array}$ & $\begin{array}{l}\text { Transcript } \\
\text { (splice } \\
\text { variants) }\end{array}$ & $\begin{array}{l}\text { CGC/ Other } \\
\text { names }\end{array}$ & $\begin{array}{l}\text { Predicted identity or } \\
\text { function }\end{array}$ & $\begin{array}{l}\text { Number of } \\
\text { amino acids }\end{array}$ & $\begin{array}{c}\text { Identity to } C . \\
\text { briggsae/H. } \\
\text { sapiens homologs } \\
(\%)\end{array}$ \\
\hline & & & $\begin{array}{l}\text { hnRNP-F and related } \\
\text { RNA-binding proteins }\end{array}$ & & \\
\hline eIF4E-1 & F53A2.6 & IFE-1 & $\begin{array}{l}\text { mRNA cap-binding } \\
\text { protein }\end{array}$ & 212 & $95 / 40$ \\
\hline eIF4E-2 & R04A9.4 & IFE-2 & $\begin{array}{l}\text { mRNA cap-binding } \\
\text { protein }\end{array}$ & 228 & $98 / 40$ \\
\hline eIF4E-3 & $\begin{array}{c}\mathrm{B} 0348.6(\mathrm{a}, \mathrm{b} \\
\mathrm{c})\end{array}$ & IFE-3 & $\begin{array}{l}\text { mRNA cap-binding } \\
\text { protein }\end{array}$ & $248,251,250$ & $99 / 47$ \\
\hline eIF4E-4 & C05D9.5 & IFE-4 & $\begin{array}{l}\text { mRNA cap-binding } \\
\text { protein }\end{array}$ & 212 & $\begin{array}{c}95 / 30 \text { to eIF4E } \\
\text { and } 48 \% \text { to } \\
4 \mathrm{E}-\mathrm{HP}\end{array}$ \\
\hline eIF4E-5 & $\begin{array}{l}\text { Y57A10A.30 } \\
(a, b)\end{array}$ & IFE-5 & $\begin{array}{l}\text { mRNA cap-binding } \\
\text { protein }\end{array}$ & 240,201 & $80 / 40$ \\
\hline eIF4G & $\mathrm{M} 110.4(\mathrm{a}, \mathrm{b})$ & IFG-1 & $\begin{array}{c}\text { Translation initiation } \\
\text { factor 4F, ribosome/ } \\
\text { mRNA-bridging } \\
\text { subunit }\end{array}$ & 1155,1156 & $99 / 27$ \\
\hline eIF4H & $\mathrm{T} 12 \mathrm{D} 8.2$ & - & $\begin{array}{c}\text { mRNA cleavage and } \\
\text { polyadenylation factor I } \\
\text { complex, subunit } \\
\text { RNA15 }\end{array}$ & 207 & $74 / 33$ \\
\hline eIF5 & $\begin{array}{c}\mathrm{C} 37 \mathrm{C} 3.2(\mathrm{a}, \mathrm{b} \\
\mathrm{c})\end{array}$ & - & $\begin{array}{l}\text { Translation initiation } \\
\text { factor } 5\end{array}$ & $436,402,413$ & $99 / 48$ \\
\hline eIF5A & F54C9.1 & IFF-2 & $\begin{array}{l}\text { Translation initiation } \\
\text { factor } 5 \text { homolog }\end{array}$ & 161 & $99 / 61$ \\
\hline eIF5A & T05G5.10 & IFF-1 & $\begin{array}{l}\text { Translation initiation } \\
\text { factor } 5 \text { homolog }\end{array}$ & 161 & $99 / 57$ \\
\hline eIF5B & Y54F10BM.2 & - & $\begin{array}{l}\text { Translation initiation } \\
\text { factor } 5 \mathrm{~B}\end{array}$ & 1173 & $82 / 48$ \\
\hline \multicolumn{6}{|c|}{ Elongation factors } \\
\hline eEF1A & F31E3.5 & EFT-3 & $\begin{array}{l}\text { Translation elongation } \\
\text { factor } 1 \alpha\end{array}$ & 436 & $99.8 / 83$ \\
\hline eEF1A & $\begin{array}{l}\text { R03G5.1 (a, b, } \\
\text { c, d) }\end{array}$ & EFT-4 & $\begin{array}{c}\text { Translation elongation } \\
\text { factor } 1 \alpha\end{array}$ & $463,77,267,429$ & $99.8 / 84$ \\
\hline eEF1B & Y41E3.10 & - & $\begin{array}{c}\text { Elongation factor } 1 \beta / \delta \\
\text { chain }\end{array}$ & 285 & $50.5 / 40$ \\
\hline eEF1B & F54H12.6 & - & $\begin{array}{c}\text { Elongation factor } 1 \beta / \delta \\
\text { chain }\end{array}$ & 213 & $99.5 / 38$ \\
\hline eEF2 & F25H5.4 & EFT-2 & $\begin{array}{c}\text { Homolog of translation } \\
\text { elongation factor } 2\end{array}$ & 852 & $89 / 76$ \\
\hline eEF2 & ZK328.2 & EFT-1 & Elongation factor 2 & 974 & $99 / 38$ \\
\hline \multicolumn{6}{|c|}{ Termination factors } \\
\hline eRF1 & T05H4.6(a,b) & - & $\begin{array}{l}\text { Peptide chain release } \\
\text { factor } 1\end{array}$ & 443,559 & $99.8 / 80$ \\
\hline eRF3 & H19N07.1 & - & $\begin{array}{l}\text { Peptide chain release } \\
\text { factor } 3\end{array}$ & 532 & $99.8 / 63$ \\
\hline
\end{tabular}


eIF2 factors. Both eIF2 and eIF2A catalyze the binding of Met-tRNA to the 40S ribosomal subunit, the former requiring GTP and the latter, an AUG codon (Zoll et al., 2002). eIF2 is composed of three subunits, $\alpha, \beta$, and $\gamma$. eIF2 $\beta$ has also been reported to bind mRNA and contributes, together with eIF2 $\gamma$, to GTP and Met-tRNA binding. Inactivation of either of these genes is lethal. Surprisingly, eIF2 $\alpha$ deletion mutants are viable but have defects in growth and larval development. Yeast eIF2A is not an essential protein, but deletion of $C$. elegans eIF2A is embryonically lethal. eIF2B is a heteropentameric complex that is essential in yeast and mammalian cells. In $C$. elegans, inactivation of either the $\beta, \gamma$ (Kuwabara and Shah, 1994), or $\varepsilon$ subunits causes growth defects, larval arrest, or embryonic lethality.

eIF4 factors. Two splice-variants of eIF4G, encoded by ifg-1, have been identified in C. elegans (Long et al., 2002; Kamath et al., 2003). Although IFG-1 shows low identity to human eIF4G, its role as a translation factor was confirmed by its retention on $\mathrm{m}^{7}$ GTP-Sepharose (Keiper and Rhoads, unpublished data) and by its presence in $48 \mathrm{~S}$ initiation complexes (Dinkova et al., 2005). ifg-1 inactivation results in developmental arrest and embryonic lethality (Long et al., 2002).

eIF4E is encoded by five genes in C. elegans, ife-1 through ife-5 (Jankowska-Anyszka et al., 1998; Keiper et al., 2000; Figure 3). The five proteins can be grouped into three classes based on amino acid sequence identity, cap-binding specificity, and knockout phenotype (Table 2). Some isoforms bind both 2,2,7-trimethylguanosine (TMG)-containing caps as well as 7-methylguanosine (MMG)-containing caps, whereas other isoforms bind only the latter. Cap selectivity is determined by the dimensions and flexibility of the cap-binding pocket (Miyoshi et al., 2002). IFE-1 is bound to $\mathrm{P}$ granules through an interaction with PGL-1 and is required for spermatogenesis (Amiri et al., 2001). In the case of IFE-4, inactivation of the gene produces an Egl phenotype, low brood size, and a defect in food sensation (Dinkova et al., 2005). The translational efficiency (polysomal distribution) of only 1\% of mRNAs is affected by ife-4 deletion, but diminished levels of the encoded proteins are consistent with the complex phenotype.

Table 2. Properties of five C. elegans isoforms of eIF4E

\begin{tabular}{|c|c|c|c|c|c|c|}
\hline Class & $\begin{array}{l}\text { eIF4E } \\
\text { isoform }\end{array}$ & $\begin{array}{l}\text { Cap-binding } \\
\text { specificity }\end{array}$ & $\begin{array}{l}\text { RNAi } \\
\text { phenotype }\end{array}$ & $\begin{array}{l}\text { Tissue } \\
\text { distribution }\end{array}$ & \begin{tabular}{|l} 
Knockout \\
mutant \\
phenotype
\end{tabular} & $\begin{array}{l}\text { Postulated physiological } \\
\text { role }\end{array}$ \\
\hline $\mathbf{A}$ & IFE-3 & MMG & Lethal & $\begin{array}{l}\text { Soma Germ } \\
\text { line }\end{array}$ & Emb & General translation \\
\hline \multirow{3}{*}{ B } & IFE-1 & $\begin{array}{l}\text { MMG } \\
\text { TMG }\end{array}$ & $\begin{array}{l}\text { Viable }^{\mathrm{a}} \\
\text { Spe }\end{array}$ & Germ line & Spe & $\begin{array}{l}\text { Regulation of P granules } \\
\text { mRNA translation }\end{array}$ \\
\hline & IFE-2 & $\begin{array}{l}\text { MMG } \\
\text { TMG }\end{array}$ & Viable $^{\mathrm{a}}$ & Soma & Unknown & Unknown \\
\hline & IFE-5 & $\begin{array}{l}\text { MMG } \\
\text { TMG }\end{array}$ & Viable $^{\mathrm{a}}$ & Unknown & Unknown & Unknown \\
\hline $\mathbf{C}$ & IFE-4 & MMG & $\begin{array}{l}\text { Viable } \\
\text { Egl }\end{array}$ & $\begin{array}{l}\text { Neurons } \\
\text { Muscle }\end{array}$ & Egl & $\begin{array}{l}\text { Specific mRNA } \\
\text { translation during } \\
\text { development }\end{array}$ \\
\hline References & & $\begin{array}{l}\text { Jankowska- } \\
\text { Anyszka et al., } \\
\text { 1998; Keiper et } \\
\text { al., 2000; Miyoshi } \\
\text { et al., 2002; } \\
\text { Stachelska et al., } \\
2002\end{array}$ & $\begin{array}{l}\text { Keiper et al., } \\
\text { 2000; Amiri } \\
\text { et al., 2001; } \\
\text { Dinkova et } \\
\text { al., } 2005\end{array}$ & $\begin{array}{l}\text { Amiri et al., } \\
2001 ; \\
\text { Dinkova et } \\
\text { al., } 2005\end{array}$ & $\begin{array}{l}\text { Amiri et al., } \\
\text { 2001; } \\
\text { Dinkova et } \\
\text { al., } 2005\end{array}$ & $\begin{array}{l}\text { Amiri et al., 2001; } \\
\text { Dinkova et al., 2005; } \\
\text { Trutschl et al., } 2005\end{array}$ \\
\hline
\end{tabular}

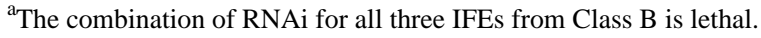




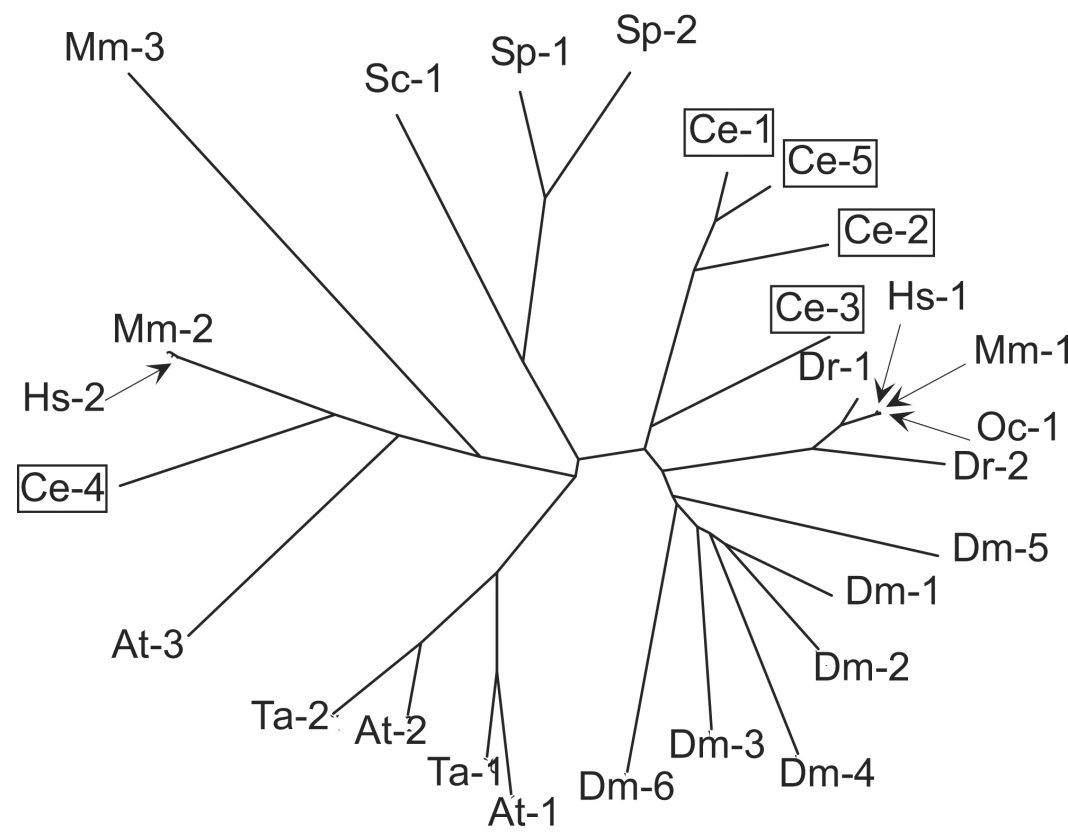

Figure 3. Homologies among eIF4E isoforms. Amino acid sequence alignments were performed using Vector NTI 9.0 .0 with a gap penalty of 3.0 and a gap extension penalty of 0.1. Multiple sequence alignments were used to calculate protein distance values and construct a phylogenetic tree with PHYLIP software on the Institut Pasteur server. eIF4E isoforms from C. elegans are indicated in boxes. NCBI accession numbers are indicated. A. thaliana: At-1, Y10548; At-2, Y10547; At-3, AF028809. C. elegans: Ce-1, NM_067350; Ce-2, NM_075693; Ce-3, NM_171920; Ce-4, AF214651; Ce-5, NM_064207. D. rerio: Dr-1, AF257519; Dr-2, AF176317. D. melanogaster: Dm-1, NM_168334; Dm-2, NM_139795; Dm-3, NM_139903; Dm-4, NM_166870; Dm-5, NM 143397; Dm-6, NM 139937. H. sapiens: Hs-1, M15353; Hs-2, AF047695. M. musculus: Mm-1, M61731; Mm-2, AF068116; Mm-3, AK005054 O.cuniculus: Oc-1, X61939. S. cerevisiae: Sc-1, M15436. S. pombe: Sp-1, X99444; Sp-2, AL031852, T. aestivum: Ta-1, Z12616; Ta-2, M95819.

Nine C. elegans gene products are homologous to eIF4A (Table 1; Roussell and Bennett, 1992; Gonczy et al., 2000). The products of F57B9.6 and F57B9.3 are the most homologous to mammalian eIF4A-1 and eIF4A-2. Others (Y65B4A.6 and F33D11.10) may be involved in splicing or nonsense-mediated decay, similar to mammalian eIF4A-3. Some may play a specific role in germline cells (C07H6.5) or in nuclear export (C26D10.2, T26G10.1, T07D4.4, and F53H1.1). Knockout of any eIF4A-like gene except T07D4.4 causes reproductive defects or embryonic lethality.

Other initiation factors and interacting proteins. eIF1, eIF3, and eIF5 form a multifactor complex in yeast that is required for assembly of the $43 \mathrm{~S}$ initiation complex. C. elegans eIF5 and eIF1 are essential for growth and embryonic development. There are C. elegans homologs for all 12 eIF3 subunits present in higher eukaryotes (Asano et al., 1997), whereas yeast eIF3 has only five subunits. Loss of eIF3a (C27D11.1) produces an Egl phenotype (Desai and Horvitz, 1989). Both eIF3a and eIF3d are involved in meiotic divisions (Gonczy et al., 2000). Another eIF3a homolog (F55H2.6) is possibly involved in mitochondrial morphology and distribution. Inactivation of eIF5B results in larval arrest and sterility (Maeda et al., 2001). C. elegans contains three PABP homologs. PAB-2 (F18H3.3) has the highest similarity to human cytoplasmic PABP. PAB-1 (Y106G6H.2) is essential for gonad development, and PAB-2 is apparently important for somatic development (Ciosk et al., 2004). PAB-3 (C17E4.5) is more similar to human nuclear PABP and is probably not involved in translation.

Elongation and termination factors $C$. elegans has two identical eEF1A homologs that are products of different genes, eft-3 (Seydoux and Fire, 1994) and eft-4 (Kamath et al., 2003). EFT-3 is required for embryonic viability, fertility, and germline maintenance. There are two homologs of eEF1B, one of which (F54H12.6) is essential for viability while the other (Y41E3.10) is not. The two eEF2 homologs, EFT-1 (Ofulue and Candido, 1992) and EFT-2 (Ofulue and Candido, 1991; Nollen et al., 2004), are expressed during all stages and are encoded by essential genes. eRF1 has two splice variants whereas eRF3 has only one. Both genes are essential for embryonic and larval development, growth, and locomotion.

\section{Structural features of mRNA that affect translational efficiency}

A distinctive feature of $C$. elegans is the presence of polycistronic pre-mRNA transcribed from operons (Blumenthal and Gleason, 2003). Translational control of individual mRNAs relies on cis-regulatory elements that 
include the cap, the 5'-terminal spliced leader (SL), and additional sequence elements in 5'- and 3'-untranslated regions (UTRs).

\subsection{5'-terminal structures}

Spliced leaders. A SL is added to mature mRNA via trans-splicing in nematodes and some other metazoans (Bektesh et al., 1988; Evans et al., 1994; Stover and Steele, 2001). The SL consists of a conserved 22-nt sequence (Conrad et al., 1991; Blumenthal and Steward, 1997). In C. elegans, either SL1 or SL2 (or a variant such as SL3, SL4, etc.) is added to 70\% of pre-mRNAs (Blumenthal and Gleason, 2003). SL1 is usually trans-spliced to mRNAs transcribed from the first cistron in an operon or to monocistronic mRNAs, whereas SL2 and its variants are trans-spliced to products of downstream cistrons.

Caps. Those mRNAs that undergo trans-splicing carry a TMG-cap and SL, whereas those that undergo only. cis-splicing carry an MMG-cap and no SL (Van Doren and Hirsh, 1990). The small nuclear RNA that donates the SL contains a TMG-cap (Zorio et al., 1994; Evans et al., 1997). MMG- and TMG-caps are recognized by some but not all eIF4E isoforms (Table 2).

$5^{\prime} U T R$. Regulatory features of the 5'UTRs of mRNAs in general involve length, secondary structure, upstream open-reading frames, and specific sequences that interact with RNA binding proteins (Gingras et al., 1999). The trans-splicing processing of many $C$. elegans mRNAs results in a relatively short 5'UTR in which the SL is located near the AUG codon (Blumenthal and Steward, 1997). A few C. elegans mRNAs, e.g., gna-2, contain long 5'UTRs that harbor upstream open-reading frames (Lee and Schedl, 2004), which have a profound effect on translation efficiency in other organisims (Morris and Geballe, 2000).

Effects of 5'-terminal structures on translational efficiency. Mechanisms of regulation mediated by 5'-terminal structures remain largely unknown for $C$. elegans. Both MMG- and TMG-containing mRNAs are found on polysomes (Liou and Blumenthal, 1990). In Ascaris lumbricoides, mutations in the SL1 sequence alter efficiency of translation (Maroney et al., 1995). TMG-capped mRNAs are poorly translated in mammalian cell-free translational systems (Darzynkiewicz et al., 1988), but a TMG-cap and SL stimulate translation in an Ascaris suum translation system (Lall et al., 2004). Interestingly, an optimal distance from SL to AUG for translational efficiency can be demonstrated in this system. The translational synergism between cap and poly(A) is greater for TMG than MMG. The well described translational regulator GLD-1 also interacts with 5'UTR sequences (Lee and Schedl, 2004).

\subsection{3'-terminal structures}

$3^{\prime} U T R$. Translational regulatory elements at the 3'UTR play important roles in C. elegans mRNA expression (see WormBook chapters on Translational control of maternal RNAs and RNA-binding proteins). The elements first described as DREs (direct repeat elements; Goodwin et al., 1993) and later re-named TGEs (tra GLI elements; Jan et al., 1997) are found within the 3'UTR of tra-2 mRNA and negatively regulate its expression in germ line and somatic cells. The trans-acting factor for TGEs was identified as GLD-1 (Jan et al., 1999). A 5-nucleotide sequence element in the 3'UTR of fem-3 mRNA, cuUCUUGu, also exerts translational regulation (Anderson and Kimble, 1997). Another kind of 3'UTR element that represses translation is the lin-4 complementary element (LCE) found in lin-14 and lin-28 mRNAs (Wightman et al., 1993; Seggerson et al., 2002). This element is bound by the microRNA lin-4 (Moss et al., 1997; see C. elegans microRNAs). Mutations in these 3'UTR elements disrupt the translational regulation of their mRNAs (see WormBook chapters referenced above).

$\operatorname{poly}(\mathrm{A})$ The poly(A) tract is added by a poly(A) polymerase after specific cleavage during mRNA splicing. The nuclear polyadenylation signal consists of an AAUAAA sequence 20-30 nt upstream of the cleavage site (Blumenthal, 1995; Hajarnavis et al., 2004). In C. elegans, GLD-2 is a putative catalytic subunit of cytoplasmic poly(A) polymerase that is likely recruited to mRNAs by interaction with RNA binding proteins such as GLD-3 (Wang et al., 2002). Cytoplasmic polyadenylation also requires a cytoplasmic polyadenylation element (CPE), located upstream of the polyadenylation site, which is recognized by specific proteins (CPEBs).

Effects of 3'-terminal structures on tranlational efficiency. Although there are many instances in which specific structures in the 3'UTR have been shown to affect translational efficiency in C. elegans and other organisms (Kuersten and Goodwin, 2003), the molecular interactions responsible for these effects are only partially understood. In Xenopus oocytes, CPEB binds and sequesters eIF4E through an intermediary protein, Maskin (Mendez and Richter, 2001). In Drosophila embryos, there is a similar interaction between the 3'UTR-binding factor Smaug and eIF4E, mediated by another protein, Cup (Nelson et al., 2004). However, in C. elegans the translational 
component(s) involved in GLD-1-mediated regulation remain unknown (Jan et al., 1999; Marin and Evans, 2003; Lee and Schedl, 2004). The other 3'-terminal element, the poly(A) tract, increases the rate of translational initiation in yeast and plants due to the binding of PABP to a specific site near the N-terminus of eIF4G (Tarun and Sachs, 1996; Le et al., 1997; see Figure 2). Poly(A) stabilizes the PABP•eIF4G•eIF4E complex, which in turn leads to enhanced translational re-initiation (Wakiyama et al., 2000). As discussed below, there are several regulatory mechanisms in $C$. elegans that involve changing the poly $(\mathrm{A})$ length.

\section{Regulation of Translation}

Many of the translational mechanisms that have been well described and characterized in other organisms (Sonenberg et al., 2000) have not yet been demonstrated in C. elegans. These can be divided into two broad classes, modification of translation factors and modification of mRNA structure. However, the existence of homologous translation factors (Table 1) and signal transduction components (Table 3) suggests that previously discovered mechanisms operate in C. elegans as well.

Table 3. Components of signal transduction pathways implicated in translational control

\begin{tabular}{|c|c|c|c|}
\hline $\begin{array}{l}\text { Predicted signal } \\
\text { transduction } \\
\text { component }\end{array}$ & $\begin{array}{l}\text { Transcript (splice } \\
\text { variants) }\end{array}$ & $\begin{array}{l}\text { CGC/ Other } \\
\text { names }\end{array}$ & $\begin{array}{c}\text { Predicted identity or function (WormBase, } \\
\text { release WS138) }\end{array}$ \\
\hline P70S6K & Y47D3A.4 & CKU-70 & $\begin{array}{l}\text { DNA-binding subunit of a DNA-dependent } \\
\text { protein kinase }\end{array}$ \\
\hline TAP42 & Y71H2B.3 & & Protein phosphatase $2 \mathrm{~A}$-associated protein \\
\hline TIP41 & ZK688.9 & & Uncharacterized conserved protein \\
\hline SIT4.1 & Y75B8A.30 & PPH-4.1 & $\begin{array}{l}\text { Serine/threonine-specific protein phosphatase } \\
\text { involved in glycogen accumulation }\end{array}$ \\
\hline SIT4.2 & Y49E10.3a & PPH-4.2 & $\begin{array}{l}\text { Serine/threonine-specific protein phosphatase } \\
\text { involved in glycogen accumulation }\end{array}$ \\
\hline Akt & C12D8.10 (a, b, c) & AKT-1 & Ortholog of serine/threonine kinase Akt/PKB \\
\hline PERK & F46C3.1 & PEK-1 & Human PERK kinase homolog \\
\hline PEK & Y38E10A.8 & & eIF2 $\alpha$ kinase PEK/EIF2AK3 \\
\hline MKK7/JNKK2 & K08A8.1 & MEK-1/ KIN-17 & MKK7/JNKK2 \\
\hline MKK7/JNKK2 & F35C8.3 & JKK-1 & JNK Kinase \\
\hline MKK4 & F42G10.2 & MKK-4 & MKK (MAP kinase kinase) homolog \\
\hline MAPK7/ERK5 & W06B3.2 & SMA-5 & MAPK7/ERK5 \\
\hline MAPK7 & C04G6.1 & MAP-2 & Mitogen-activated protein kinase 7 , isoform 1 \\
\hline MAPK7 & F09C12.2 & & Mitogen-activated protein kinase \\
\hline МАР2K & Y54E10BL.6 & $\begin{array}{l}\text { MEK-2/ LET-537/ } \\
\text { GLV-1 }\end{array}$ & MAP kinase kinase or ERK kinase \\
\hline ERN1/IRE1 & $\mathrm{C} 41 \mathrm{C} 4.4$ & IRE-1 & IRE1 kinase related \\
\hline TOR & B0261.2 & LET-363 & $\begin{array}{c}\text { Ortholog of } S . \text { cerevisiae Tor1p and Tor } 2 \mathrm{p} \text { and } \\
\text { human FRAP1 }\end{array}$ \\
\hline PI3K & C46B6.6 & SMG-1/ MAB-1 & PI-3-kinase-related kinase SMG-1 isoform 2 \\
\hline PI3K like & T06E4.3 & ATL-1 & ATM (ataxia telangectasia mutated)-like \\
\hline PI4K & $\mathrm{ZC} 8.6$ & & Phosphatidylinositol 4-kinase \\
\hline PI4K & C56A3.8 & & Phosphatidylinositol 4-kinase \\
\hline Raptor & C10C5.6 (a,b) & DAF-15 & Abnormal dauer formation \\
\hline
\end{tabular}




\subsection{Mechanisms involving translation factor modification}

Covalent modification of a translation factor. The unfolded protein response (UPR) is a transcriptional and translational signaling pathway activated by the accumulation of unfolded proteins in the endoplasmic reticulum (ER; Zhang and Kaufman, 2004). This involves activation of an eIF2 $\alpha$ kinase, PEK, causing global inhibition of translation initiation and allowing time to remedy the folding problem. C. elegans PEK-1 was expressed in yeast and found to inhibit growth by hyperphosphorylation of eIF2 $\alpha$ and inhibition of eIF2B (Sood et al., 2000). UPR gene transcription and survival upon ER stress also requires ire-1-mediated splicing of $x b p-1$ mRNA (Shen et al., 2001). ire-1/xbp-1 acts with pek-1 in complementary pathways that are essential for worm development, survival, and ER homeostasis. Furthermore, pek-1 mutants have shortened life spans (Harding et al., 2003).

Sequestration of a translation factor. TOR is a highly conserved protein kinase that controls cell growth and division in eukaryotes. In mammals, mTOR regulates translation by phosphorylation of p70 S6 kinase (S6K) and the eIF4E-binding protein 4E-BP1 (Gingras et al., 2001). The latter event releases eIF4E from a sequestered form, making it available to bind eIF4G (Figure 2). Raptor is a mTOR-binding protein that is necessary for the mTOR-catalyzed phosphorylation of 4E-BP1 and S6K (Hara et al., 2002). In yeast, TOR also regulates translation through eIF4E by a mechanism involving the phosphatases Sit4 and PP2A and the phosphatase-binding protein Tap42 (Jiang and Broach, 1999). Tip41 negatively regulates TOR by binding and inhibiting Tap42 (Jacinto et al., 2001).

In C. elegans, cTOR (let-363) deficiency causes developmental arrest and intestinal atrophy (Long et al., 2002). The phenotype resembles that of RNAi knockdown of eIF4G, eIF2 $\alpha$, and eIF2 $\beta$, but not S6K, Tip41, or Tap42. RNAi of Raptor (daf-15) yields an array of phenotypes resembling those of cTOR knockout. Deficiency of both let-363 (Vellai et al., 2003) and daf-15 (Jia et al., 2004) extends adult lifespan, while mutations in either gene result in dauer-like larval arrest (Jia et al., 2004). To date, a C. elegans 4E-BP1 homolog has not been identified. The protein phas-1 (WP:CE30964; Agostoni et al., 2002; another name for 4E-BP1 is PHAS-I) is unrelated to mammalian and Drosophila 4E-BP1.

The presence of IFE-1 in P granules (Amiri et al., 2001) and its absence from initiation complexes (Dinkova et al., 2005) may represent another regulatory mechanism involving sequestration of a translation factor. A number of mRNAs have been found in $\mathrm{P}$ granules, some of which have been shown to be translationally controlled (Schisa et al., 2001). P granules also contain four GLH RNA helicases similar to eIF4A (Gruidl et al., 1996; Kuznicki et al., 2000). In Drosophila, VASA is a germline-specific ATP-dependent RNA helicase, homologous to the GLH proteins, that is required for translation of at least two mRNAs, gurken and nanos, through interaction with eIF5B (Styhler et al., 1998; Johnstone and Lasko, 2004). Also, eIF5A is required for PGL-1 localization (Hanazawa et al., 2004). The presence of all these translational components in $P$ granules may signify regulation of germline-specific mRNA translation.

\subsection{Mechanisms involving mRNA modification}

The translation of some C. elegans mRNAs is regulated by 3'UTR-binding proteins that alter poly(A) length (Kuersten and Goodwin, 2003). There are four CPEB homologs, CBP-1, CPB-2, CPB-3, and FOG-1 (Luitjens et al., 2000). CPB-1 is essential for progression through meiosis and is present in germ cells just before spermatogenesis. CPB-1 physically interacts with FBF, another RNA-binding protein and 3' UTR regulator. Similarities between FOG-1 and the CPEB proteins of Xenopus and Drosophila suggest that FOG-1 controls germ cell fates by regulating the translation of specific messenger RNAs.

A specific mRNA that undergoes regulated changes in poly(A) length is tra-2 mRNA, whose translation must be repressed for male development. A possible mechanism of action is suggested by the observation that TGEs control the length of the poly(A) tract in a Xenopus system (Thompson et al., 2000). Similarly, a 5-nt element in the 3'UTR of fem-3 mRNA controls the length of the poly(A) tract (Ahringer and Kimble, 1991). fem-3 must be downregulated to allow the switch from spermatogenesis to oogenesis. FBF and Nanos-3 interact with each other and repress translation of fem-3 mRNA (Kraemer et al., 1999). GLD-3 also physically interacts with FBF to interfere with FBF binding to the 3'UTR of fem-3 mRNA (Eckmann et al., 2002). GLD-3 promotes the transition from mitosis to meiosis together with the putative GLD-2 poly(A) polymerase. FBF also binds specifically to elements in the 3'UTR of gld-3S mRNA and regulates gld-3 expression (Eckmann et al., 2004). 


\subsection{Known instances of translational regulation that occur but through unknown mechanisms}

The translation of several other mRNAs is known to be regulated through the 3'UTR, but this cannot yet be explained within the framework of known translational control mechanisms. A 34-nucleotide region of the 3'UTR of glp- 1 mRNA contains two regulatory elements, one that represses translation in germ cells and posterior cells of the early embryo, and one that inhibits repressor activity to promote translation in the embryo (Marin and Evans, 2003). GLD-1 binds to this repressor element. MEX-3 is also expressed in anterior blastomere cells and is required for repression of pal-1 mRNA translation (Hunter and Kenyon, 1996; Draper et al., 1996).

A different type of 3'UTR regulation is seen with the heterochronic genes, which are temporally controlled to specify the timing of developmental events. lin-14 and lin-28 encode proteins that are required for temporal execution of cell lineages during larval development. lin-14, lin-28, lin-42, and daf-12 mRNAs contain a conserved element in the 3'UTR, the loss of which causes a gain of function (Seggerson et al., 2002). let-7 encodes a temporally regulated 21-nucleotide RNA that is complementary to elements in heterochonic mRNA 3'UTRs and regulates their translation (Reinhart et al., 2000). A second regulatory RNA, lin-4, negatively regulates lin-14 and lin-28 through RNA-RNA interactions with their 3'UTR (Moss et al., 1997). lin-28 is repressed during normal development by a mechanism that acts on its mRNA after translation initiation (Seggerson et al., 2002).

\subsection{Future directions for protein synthesis research in C. elegans}

As illustrated throughout this chapter, several key developmental pathways in C. elegans are predominantly governed by translational mechanism. However, translation per se has received little attention. Even though one can find C. elegans homologs for most of the RNAs and proteins that make up the translational machinery (Table 1), few of these have been isolated, functionally identified, or studied at the biochemical level. This deficiency obscures the molecular mechanisms responsible for well characterized physiological processes. Another shortcoming is the absence of a cell-free translation system, although such systems have been developed in two other nematodes, Ascaris lumbricoides (Maroney et al., 1995) and Ascaris suum (Lall et al., 2004). The most interesting unexplored questions may involve changes in the translation of individual mRNAs in various physiological conditions or after genetic manipulations. Given the highly developed state of $C$. elegans genomics, it can be expected that future application of computational tools, including data visualization (Trutschl et al., 2005), will help detect new instances of translational control.

\section{Acknowledgements}

This work was supported by Grant GM20818 from the National Institutes of Health. We thank Brett Keiper for sharing preliminary data and for helpful discussions, Aaron Lefebvre for protein sequence alignments and construction of Figure 3, and Lisa Whittington for editorial assistance.

\section{References}

Agostoni, E., Gobessi, S., Petrini, E., Monte, M., and Schneider, C. (2002). Cloning and characterization of the $C$. elegans gas1 homolog: phas-1. Biochim. Biophys. Acta 1574, 1-9. Abstract

Ahringer, J., and Kimble, J. (1991). Control of the sperm-oocyte switch in Caenorhabditis elegans hermaphrodites by the fem-3 3' untranslated region. Nature 349, 346-348. Abstract Article

Albertson, D. (1984). Localization of the ribosomal genes in Caenorhabditis elegans chromosomes by in situ hybridization using biotin-labeled probes. EMBO J. 3, 1227-1234. Abstract

Amaar, Y., and Baillie, D. (1993).Cloning and characterization of the $C$. elegans histidyl-tRNA synthetase gene [published erratum appears in Nucleic Acids Res. 1993 Dec 25;21(25):6050-1]. Nucl. Acids Res. 21 , $4344-4347$. Abstract

Amiri, A., Keiper, B.D.,Kawasaki, I., Fan, Y., Kohara, Y., Rhoads, R.E., and Strome, S. (2001). An isoform of eIF4E is a component of germ granules and is required for spermatogenesis in C. elegans.Development 128, 3899-3912. Abstract 
Anderson, P., and Kimble, J. (1997). mRNA and translation. In C. Elegans II, D.L. Riddle, T. Blumenthal, B.J. Meyer,and J.R. Priess,eds. (Cold Spring Harbor: Cold Spring Harbor Laboratory Press), pp. 185-208.

Asano, K., Clayton, J., Shalev, A., and Hinnebusch, A.G. (2000). A multifactor complex of eukaryotic initiation factors, eIF1, eIF2, eIF3, eIF5, and initiator tRNA(Met) is an important translation initiation intermediate in vivo. Genes Dev. 14, 2534-2546. Abstract Article

Asano, K., Vornlocher, H.-P., Richter-Cook, N.J., Merrick, W.C., Hinnebusch, A.G., and Hershey, J.W.B. (1997). Structure of cDNAs encoding human eukaryotic initiation factor 3 subunits. J. Biol. Chem. 272, $27042-27052$. Abstract Article

Bektesh, S., Van Doren, K., and Hirsh, D. (1988). Presence of the Caenorhabditis elegans spliced leader on different mRNAs and in different genera of nematodes. Genes Dev. 2, 1277-1283. Abstract

Blumenthal, T. (1995). Trans-splicing and polycistronic transcription in Caenorhabditis elegans. Trends Genet. 11, 132-136. Abstract Article

Blumenthal, T., and Gleason, K. (2003). Caenorhabditis elegans operons: form and function. Nat. Rev. Genet. 4, 112-120. Abstract Article

Blumenthal, T., and Steward, K. (1997). RNA processing and gene structure. In: C. Elegans II, D.L. Riddle, T. Blumenthal, B.J. Meyer, and J.R. Priess, eds. (Cold Spring Harbor, NY: Cold Spring Harbor Laboratory Press), pp. $117-145$.

Ciosk, R., DePalma, M., and Priess, J.R. (2004). ATX-2, the C. elegans ortholog of ataxin 2, functions in translational regulation in the germline. Development 131, 4831-4841. Abstract Article

Clark, B.F.C., Grunberg-Manago, M., Gupta, N.K., Hershey, J.W.B., Hinnebusch, A.G., Jackson, R.J., Maitra, U., Mathews, M.B., Merrick, W.C., Rhoads, R.E., Sonenberg, N., Spremulli, L.L., Trachsel, H., and Voorma, H.O. (1996). Prokaryotic and eukaryotic translation factors. Biochimie 78, 1119-1122. Abstract Article

Conrad, R., Thomas, J., Spieth, J., and Blumenthal, T. (1991). Insertion of part of an intron into the 5' untranslated region of a Caenorhabditis elegans gene converts it into a trans-spliced gene. Mol. Cell. Biol. 11, $1921-1926$. Abstract

Darzynkiewicz, E., Stepinski, J., Ekiel, I., Jin, Y., Haber, D., Sijuwade, T., and Tahara, S.M. (1988). $\beta$-globin mRNAs capped with $\mathrm{m}^{7} \mathrm{G}, \mathrm{m}^{2,2} \mathrm{G}$, or $\mathrm{m}^{2,2,7} \mathrm{G}$ differ in intrinsic translation efficiency. Nucl. Acids Res. 16, 8953-8962. Abstract

Desai, C., and Horvitz, H.R. (1989). Caenorhabditis elegans mutants defective in the functioning of the motor neurons responsible for egg laying. Genetics 121, 703-721. Abstract

Dinkova, T.D., Keiper, B.D., Korneeva, N.L., Aamodt, E.J., and Rhoads, R.E. (2005). Translation of a small subset of Caenorhabditis elegans mRNAs is dependent on a specific eIF4E isoform. Mol. Cell Biol. 25, 100-113. Abstract Article

Draper, B.W., Mello, C.C., Bowerman, B., Hardin, J., and Priess, J.R. (1996). MEX-3 is a KH domain protein that regulates blastomere identity in early $C$. elegans embryos. Cell 87, 205-216. Abstract Article

Eckmann, C., Kraemer, B., Wickens, M., and Kimble, J. (2002). GLD-3, a bicaudal-C homolog that inhibits FBF to control germline sex determination in C. elegans. Dev. Cell 3, 697-710. Abstract Article

Eckmann, C.R., Crittenden, S.L., Suh, N., and Kimble, J. (2004). GLD-3 and control of the mitosis/meiosis decision in the germline of Caenorhabditis elegans. Genetics 168, 147-160. Abstract Article

Ellis, R., Sulston, J., and Coulson, A. (1986). The rDNA of C. elegans: sequence and structure. Nucl. Acids Res. 14, 2345-2364. Abstract 
Evans, D., Zorio, D., MacMorris, M., Winter, C.E., Lea, K., and Blumenthal, T. (1997). Operons and SL2 trans-splicing exist in nematodes outside the genus Caenorhabditis. Proc. Natl. Acad. Sci. USA 94, 9751-9756. Abstract Article

Evans, T., Crittenden, S., Kodoyianni, V., and Kimble, J. (1994). Translational control of maternal glp-1 mRNA establishes an asymmetry in the C. elegans embryo. Cell 77, 183-194. Abstract Article

Files, J., and Hirsh, D. (1981). Ribosomal DNA of Caenorhabditis elegans. J. Mol. Biol. 149, 223-240. Abstract Article

Gabius, H., Graupner, G., and Cramer, F. (1983). Activity patterns of aminoacyl-tRNA synthetases, tRNA methylases, arginyltransferase and tubulin: tyrosine ligase during development and ageing of Caenorhabditis elegans. Eur. J. Biochem. 131, 231-234. Abstract Article

Gingras, A.-C., Raught, B., and Sonenberg, N. (1999). eIF4 initiation factors: effectors of mRNA recruitment to ribosomes and regulators of translation. Ann. Rev. Biochem. 68, 913-963. Abstract Article

Gingras, A.-C., Raught, B., and Sonenberg, N. (2001). Regulation of translation initiation by FRAP/mTOR. Genes Dev. 15, 807-826. Abstract Article

Gonczy, P., Echeverri, C., Oegema, K., Coulson, A., Jones, S., Copley, R., Duperon., J., Oegema, J., Brehm., M.,Cassin., E., Hannak, E., Kirkham, M., Pichler, S., Flohrs, K., Goessen, A., Leidel, S., Alleaume, A.M., Martin, C., Ozlu, N., Bork, P., and Hyman, A.A. (2000). Functional genomic analysis of cell division in C. elegans using RNAi of genes on chromosome III. Nature 408, 331-336. Abstract Article

Goodwin, E., Okkema, P., Evans, T., and Kimble, J. (1993). Translational regulation of tra-2 by its 3' untranslated region controls sexual identity in C. elegans. Cell 75, 329-339. Abstract Article

Gruidl, M.E., Smith, P.A., Kuznicki, K.A., McCrone, J.S., Kirchner, J., Roussell, D.L., Strome, S., and Bennett, K.L. (1996). Multiple potential germ-line helicases are components of the germ-line-specific $P$ granules of Caenorhabditis elegans. Proc. Natl. Acad. Sci. USA 93, 13837-13842. Abstract Article

Hajarnavis, A., Korf, I., and Durbin, R. (2004). A probabilistic model of 3' end formation in Caenorhabditis elegans. Nucl. Acids Res. 32, 3392-3399. Abstract Article

Hanazawa, M., Kawasaki, I., Kunitomo, H., Gengyo-Ando, K., Bennett, K., Mitani, S., and Iino, Y. (2004). The Caenorhabditis elegans eukaryotic initiation factor 5A homologue, IFF-1, is required for germ cell proliferation, gametogenesis and localization of the P-granule component PGL-1. Mech. Dev. 121, 213-224. Abstract Article

Hara, K., Maruki, Y., Long, X., Yoshino, K., Oshiro, N., Hidayat, S., Tokunaga, C., Avruch, J., and Yonezawa, K. (2002). Raptor, a binding partner of target of rapamycin (TOR), mediates TOR action. Cell 110, 177-189. Abstract Article

Harding, H., Zhang, Y., Zeng, H., Novoa, I., Lu, P., Calfon, M., Sadri, N., Yun, C., Popko, B., Paules, R., et al. (2003). An integrated stress response regulates amino acid metabolism and resistance to oxidative stress. Mol. Cell 11, 619-633. Abstract Article

Hershey, J.W.B., and Merrick, W.C. (2000). Pathway and mechanism of initiation of protein synthesis. In: Translational Control of Gene Expression, N. Sonenberg, J.W.B. Hershey, and M.B. Mathews, eds. (Cold Spring Harbor, New York: Cold Spring Harbor Laboratory Press), pp. 33-88.

Hinnebusch, A.G. (1997). Translational regulation of yeast GCN4: a window on factors that control initiator-tRNA binding to the ribosome. J. Biol. Chem. 272, 21661-21664. Abstract Article

Hinnebusch, A.G., and Fink, G.R. (1983). Positive regulation in the general amino acid control of Saccharomyces cerevisiae. Proc. Natl. Acad. Sci. USA 80, 5374-5378. Abstract

Hunter, C., and Kenyon, C. (1996). Spatial and temporal controls target pal-1 blastomere-specification activity to a single blastomere lineage in C. elegans embryos. Cell 87, 217-226. Abstract Article 
Jacinto, E., Guo, B., Arndt, K., Schmelzle, T., and Hall, M. (2001). TIP41 interacts with TAP42 and negatively regulates the TOR signaling pathway. Mol. Cell 8, 1017-1026. Abstract Article

Jan, E., Motzny, C.K., Graves, L.E., and Goodwin, E.B. (1999). The STAR protein, GLD-1, is a translational regulator of sexual identity in Caenorhabditis elegans. EMBO J. 18, 258-269. Abstract Article

Jan, E., Yoon, J.W., Walterhouse, D., Iannaccone, P., and Goodwin, E.B. (1997). Conservation of the C. elegans tra-2 3'UTR translational control. EMBO J. 16, 6301-6313. Abstract Article

Jankowska-Anyszka, M., Lamphear, B.J., Aamodt, E.J., Harrington, T., Darzynkiewicz, E., Stolarski, R., and Rhoads, R.E. (1998). Multiple isoforms of eukaryotic protein synthesis initiation factor 4E in C. elegans can distinguish between mono- and trimethylated mRNA cap structures. J. Biol. Chem. 273, 10538-10542. Abstract Article

Jia, K., Chen, D., and Riddle, D.L. (2004). The TOR pathway interacts with the insulin signaling pathway to regulate $C$. elegans larval development, metabolism and life span. Development 131, 3897-3906. Abstract Article

Jiang, Y., and Broach, J.R. (1999). Tor proteins and protein phosphatase 2A reciprocally regulate Tap42 in controlling cell growth in yeast. EMBO J. 18, 2782-2792. Abstract Article

Johnstone, O., and Lasko, P. (2004). Interaction with eIF5B is essential for Vasa function during development. Development 131, 4167-4178. Abstract Article

Jones, D., and Candido, E. (1993). Novel ubiquitin-like ribosomal protein fusion genes from the nematodes Caenorhabditis elegans and Caenorhabditis briggsae. J. Biol. Chem. 268, 19545-19551. Abstract

Kamath, R., Fraser, A., Dong, Y., Poulin, G., Durbin, R., Gotta, M., Kanapin, A., Le Bot, N., Moreno, S., Sohrmann, M., et al. (2003). Systematic functional analysis of the Caenorhabditis elegans genome using RNAi. Nature 421, 231-237. Abstract Article

Keiper, B.D., Lamphear, B.J., Deshpande, A.M., Jankowska-Anyszka, M., Aamodt, E.J., Blumenthal, T., and Rhoads, R.E. (2000). Functional characterization of five eIF4E isoforms in Caenorhabditis elegans. J. Biol. Chem. 275, 10590-10596. Abstract Article

Khosla, M., and Honda, B. (1989). Initiator tRNA ${ }^{\text {Met }}$ genes from the nematode Caenorhabditis elegans. Gene 76, 321-330. Abstract Article

Kraemer, B., Crittenden, S., Gallegos, M., Moulder, G., Barstead, R., Kimble, J., and Wickens, M. (1999). NANOS-3 and FBF proteins physically interact to control the sperm-oocyte switch in Caenorhabditis elegans. Curr. Biol. 9, 1009-1018. Abstract Article

Kuersten, S., and Goodwin, E. (2003). The power of the 3' UTR: translational control and development. Nat. Rev. Genet. 4, 626-637. Abstract Article

Kuwabara, P., and Shah, S. (1994). Cloning by synteny: identifying C. briggsae homologues of C. elegans genes. Nucl. Acids Res. 22, 4414-4418. Abstract

Kuznicki, K., Smith, P., Leung-Chiu, W., Estevez, A., Scott, H., and Bennett, K. (2000). Combinatorial RNA interference indicates GLH-4 can compensate for GLH-1; these two P granule components are critical for fertility in C. elegans. Development 127, 2907-2916. Abstract

Lall, S., Friedmann, C.C., Jankowska-Anyszka, M., Stepinksi, J., Darzynkiewicz, E., and Davis, R.E. (2004). Contribution of trans-splicing, 5'-leader length, cap-poly(A) synergism, and initiation factors to nematode translation in an Ascaris suum embryo cell-free system. J. Biol. Chem. 279, 45573-45585. Abstract Article

Le, H., Tanguay, R.L., Balasta, M.L., Wei, C.C., Browning, K., Metz, A.M., Goss, D.J., and Gallie, D.R. (1997). Translation initiation factors eIF-iso4G and eIF-4B interact with the poly(A)-binding protein and increase its RNA binding activity. J. Biol. Chem. 272, 16247-16255. Abstract Article 
Lee, B.J., Rajagopalan, M., Kim, Y.S., You, K.H., Jacobson, K.B., and Hatfield, D. (1990). Selenocysteine tRNA[Ser]Sec gene is ubiquitous within the animal kingdom. Mol. Cell Biol. 10, 1940-1949. Abstract

Lee, M.-H., and Schedl, T. (2004). Translation repression by GLD-1 protects its mRNA targets from nonsense-mediated mRNA decay in C. elegans. Genes Dev. 18, 1047-1059. Abstract Article

Liou, R.F., and Blumenthal, T. (1990). Trans-spliced Caenorhabditis elegans messenger RNAs retain trimethylguanosine caps. Mol. Cell Biol. 10, 1764-1768. Abstract

Long, X., Spycher, C., Han, Z., Rose, A., Muller, F., and Avruch, J. (2002). TOR deficiency in C. elegans causes developmental arrest and intestinal atrophy by inhibition of mRNA translation. Curr. Biol. 12, 1448-1461. Abstract Article

Luitjens, C., Gallegos, M., Kraemer, B., Kimble, J., and Wickens, M. (2000). CPEB proteins control two key steps in spermatogenesis in C. elegans. Genes Dev. 14, 2596-2609. Abstract Article

Maeda, I., Kohara, Y., Yamamoto, M., and Sugimoto, A. (2001). Large-scale analysis of gene function in Caenorhabditis elegans by high-throughput RNAi. Curr. Biol. 11, 171-176. Abstract Article

Marin, V.A., and Evans, T.C. (2003). Translational repression of a C. elegans Notch mRNA by the STAR/KH domain protein GLD-1. Development 130, 2623-2632. Abstract Article

Maroney, P.A., Denker, J.A., Darzynkiewicz, E., Laneve, R., and Nilsen, T.W. (1995). Most mRNAs in the nematode Ascaris lumbricoides are trans-spliced: a role for spliced leader addition in translational efficiency. RNA $1,714-723$. Abstract

Mendez, R., and Richter, J.D. (2001). Translational control by CPEB: a means to the end. Mol. Cell Biol. 2, 521-529. Abstract Article

Miyoshi, H., Dwyer, D.S., Keiper, B.D., Jankowska-Anyszka, M., Darzynkiewicz, E., and Rhoads, R.E. (2002). Discrimination between mono- and trimethylated cap structures by two isoforms of Caenorhabditis elegans eIF4E.

EMBO J. 21, 1-11. Abstract Article

Morris, D.R., and Geballe, A.P. (2000). Upstream open reading frames as regulators of mRNA translation. Mol. Cell Biol. 20, 8635-8642. Abstract Article

Moss, E., Lee, R., and Ambros, V. (1997). The cold shock domain protein LIN-28 controls developmental timing in C. elegans and is regulated by the lin-4 RNA. Cell 88, 637-646. Abstract Article

Nelson, D., and Honda, B. (1985). Genes coding for 5S ribosomal RNA of the nematode Caenorhabditis elegans. Gene 38, 245-251. Abstract Article

Nelson, M.R., Leidal, A.M., and Smibert, C.A. (2004). Drosophila Cup is an eIF4E-binding protein that functions in Smaug-mediated translational repression. EMBO J. 23, 150-159. Abstract Article

Nollen, E.A.A., Garcia, S.M., van Haaften, G., Kim, S., Chavez, A., Morimoto, R.I., and Plasterk, R.H.A. (2004). From the cover: genome-wide RNA interference screen identifies previously undescribed regulators of polyglutamine aggregation. Proc. Natl. Acad. Sci. USA 101, 6403-6408. Abstract Article

Ofulue, E., and Candido, E. (1991). Molecular cloning and characterization of the Caenorhabditis elegans elongation factor 2 gene (eft-2). DNA Cell Biol. 10, 603-611. Abstract

Ofulue, E., and Candido, E. (1992). Isolation and characterization of eft-1, an elongation factor 2-like gene on chromosome III of Caenorhabditis elegans. DNA Cell Biol. 11, 71-82. Abstract

Phan, L., Zhang, X., Asano, K., Anderson, J., Vornlocher, H.-P., Greenberg, J.R., Qin, J., and Hinnebusch, A.G. (1998). Identification of a translation initiation factor 3 (eIF3) core complex, conserved in yeast and mammals, that interacts with eIF5. Mol. Cell Biol. 18, 4935-4946. Abstract 
Reinhart, B., Slack, F., Basson, M., Pasquinelli, A., Bettinger, J., Rougvie, A., Horvitz, H., and Ruvkun, G. (2000). The 21-nucleotide let-7 RNA regulates developmental timing in Caenorhabditis elegans. Nature 403, 901-906. Abstract Article

Roussell, D., and Bennett, K. (1992). Caenorhabditis cDNA encodes an eIF-4A-like protein. Nucl. Acids Res. 20, 3783. Abstract

Schaller, D., Wittmann, C., Linning, R., Spicher, A., Muller, F., and Tobler, H. (1991). Cloning and expression in vitro of a gene encoding tRNA ${ }^{\text {ArgACG }}$ from the nematode Caenorhabditis elegans. Gene 97, 273-276. Abstract Article

Schisa, J., Pitt, J., and Priess, J. (2001). Analysis of RNA associated with P granules in germ cells of $C$. elegans adults. Development 128, 1287-1298. Abstract

Seggerson, K., Tang, L., and Moss, E. (2002). Two genetic circuits repress the Caenorhabditis elegans heterochronic gene lin-28 after translation initiation. Dev. Biol. 243, 215-225. Abstract Article

Seydoux, G., and Fire, A. (1994). Soma-germline asymmetry in the distributions of embryonic RNAs in Caenorhabditis elegans. Development 120, 2823-2834. Abstract

Shen, X., Ellis, R., Lee, K., Liu, C., Yang, K., Solomon, A., Yoshida, H., Morimoto, R., Kurnit, D., Mori, K., and Kaufman, R. (2001). Complementary signaling pathways regulate the unfolded protein response and are required for C. elegans development. Cell 107, 893-903. Abstract Article

Sherman, F., and Stewart, J.W. (1975). The use of iso-1-cytochrome c mutants of yeast for elucidating the nucleotide sequences that govern initiation of translation. In: Organization and Expression of the Eukaryotic Genome: Biochemical Mechanisms of Differentiation in Prokaryotes and Eukaryotes, G. Bernardi, and F. Gros, eds. (New York: Elsevier), pp. 175-191.

Sonenberg, N., Hershey, J.W.B., and Mathews, M.B., eds. (2000). Translational Control of Gene Expression (Cold Spring Harbor: Cold Spring Harbor Laboratory Press).

Sood, R., Porter, A., Ma, K., Quilliam, L., and Wek, R. (2000). Pancreatic eukaryotic initiation factor-2 [x03B1] kinase (PEK) homologues in humans, Drosophila melanogaster and Caenorhabditis elegans that mediate translational control in response to endoplasmic reticulum stress. Biochem. J. 346, 281-293. Abstract Article

Stachelska, A., Wieczorek, Z., Ruszczynska, K., Stolarski, R., Pietrzak, M., Lamphear, B., Rhoads, R., Darzynkiewicz, E., and Jankowska-Anyszka, M. (2002). Interaction of three Caenorhabditis elegans isoforms of translation initiation factor eIF4E with mono- and trimethylated mRNA 5' cap analogues. Acta. Biochim. Pol. 49, 671-682. Abstract

Stover, N.A., and Steele, R.E. (2001). Trans-spliced leader addition to mRNAs in a cnidarian. Proc. Natl. Acad. Sci. USA 98, 5693-5698. Abstract Article

Styhler, S., Nakamura, A., Swan, A., Suter, B., and Lasko, P. (1998). vasa is required for GURKEN accumulation in the oocyte, and is involved in oocyte differentiation and germline cyst development. Development $125,1569-1578$. Abstract

Tarun, S.Z., and Sachs, A.B. (1996). Association of the yeast poly(A) tail binding protein with translation initiation factor eIF-4G. EMBO J. 15, 7168-7177. Abstract

Thompson, S.R., Goodwin, E.B., and Wickens, M. (2000). Rapid deadenylation and poly(A)-dependent translational repression mediated by the Caenorhabditis elegans tra-2 3' untranslated region in Xenopus embryos. Mol. Cell Biol. 20, 2129-2137. Abstract Article

Tranquilla, T., Cortese, R., Melton, D., and Smith, J. (1982). Sequences of four tRNA genes from Caenorhabditis elegans and the expression of C. elegans tRNA ${ }^{\text {Leu }}$ (anticodon IAG) in Xenopus oocytes. Nucl. Acids Res. 10, 7919-7934. Abstract 
Trutschl, M., Dinkova, T.D., and Rhoads, R.E. (2005). Application of machine learning and visualization of heterogeneous datasets to uncover relationships between translation and developmental stage expression of $C$. elegans mRNAs. Physiol. Genomics 21, 264-273. Abstract Article

Van Doren, K., and Hirsh, D. (1990). mRNAs that mature through trans-splicing in Caenorhabditis elegans have a trimethylguanosine cap at their 5' termini. Mol. Cell Biol. 10, 1769-1772. Abstract

Vellai, T., Takacs-Vellai, K., Zhang, Y., Kovacs, A.L., Orosz, L., and Muller, F. (2003). Genetics: influence of TOR kinase on lifespan in C. elegans. Nature 426, 620. Abstract Article

Wakiyama, M., Imataka, H., and Sonenberg, N. (2000). Interaction of eIF4G with poly(A)-binding protein stimulates translation and is critical for Xenopus oocyte maturation. Curr. Biol. 10, 1147-1150. Abstract Article

Wang, L., Eckmann, C., Kadyk, L., Wickens, M., and Kimble, J. (2002). A regulatory cytoplasmic poly(A) polymerase in Caenorhabditis elegans. Nature 419, 312-316. Abstract Article

Wightman, B.C., Ha, I., and Ruvkun, G.B. (1993). Posttranscriptional regulation of the heterochronic gene lin-14 by lin-4 mediates temporal pattern formation in C. elegans. Cell 75, 855-862. Abstract Article

Zhang, K., and Kaufman, R.J. (2004). Signaling the unfolded protein response from the endoplasmic reticulum. J. Biol. Chem. 279, 25935-25938. Abstract Article

Zoll, W.L., Horton, L.E., Komar, A.A., Hensold, J.O., and Merrick, W.C. (2002). Characterization of mammalian eIF2A and identification of the yeast homolog. J. Biol. Chem. 277, 37079-37087. Abstract Article

Zorio, D., Cheng, N., Blumenthal, T., and Spieth, J. (1994). Operons as a common form of chromosomal organization in C. elegans. Nature 372, 270-272. Abstract Article

All WormBook content, except where otherwise noted, is licensed under a Creative Commons Attribution License. 